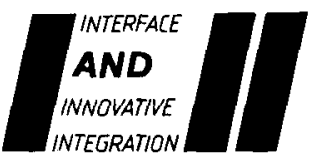

\title{
アルミの接合技術*
}

松本二郎**

\section{Joining Technique of Aluminium and it Alloys*}

by Jiro Matsumoto**

キーワート：ティグ,ミグ，抵抗スポット溶接，レーザ溶接,

電子ビーム溶接

\section{1.はじめに}

アルミニウム及びアルミニウム合金（以下アルミニウ ムという）の接合は，その敉密な表面酸化皮膜と活性度 が高く酸化しやすい特性のために，鉄銅材に比較して困 難であると考えられてきた。しかしながら，アルミニウ ムは接合加工に要するコスト高や，工程の複雑さ及び製 作範囲等改善されるべき点は多数あると考えられるもの の,この材料の軽量性, 耐食性, 加工性, 押出性, 高熱 伝运性及び非磁性等の数多くの有用な特性を生かして, その利用範囲が非常に広がってきている。またその接合 法にも工夫がされており，少なくとも接合を駆使した製 品の品質レベルは，鉄鋼材料をはじめ他の非鉄金属材料 のそれに比較しても遜色のないレべルにきていると考え る.本章ではアルミニウム接合の概要について説明する。

\section{2. 接 合 法}

金属の接合法を大別すると機械的接合，接着剂に上る 接合及び溶接法がある。そしてこのうちの溶接法には分 類の方法にもよるが,細かく分類すれば 50 程類にも達す る溶接法が開発され，色々な用途に駆使されている。こ れらの溶接法を大別すると表 $1 に$ 示すように䖵接・圧 接・ろう接の 3 種類に分什られる。

哕接は接合する母材を溶融点以上に加熱・溶融して接 合する方法であり接合に対して区力を加えることはしな

"原稿受付 平成 3 年 2 月 20 日

軽技研 Nikkei Techno-Research Ltd.
い.この融接では母材を溶融させるために相当な高温に 加熱する必要があり，加熱の熱源によりガス溶接，アー ク溶接からレーザ溶接まで色々な種類に分類される，表 2 にアルミニウムの溶接に現在利用されている主な啒接 の特徴と適用例を示す。

压接は虽点以上に加熱するものもあり，また熱を加え ずに常温で行うものもあるが、いずれにしても加圧して 接合する溶接法である，超音波溶接，爆発溶接及び冾間 圧接などは，ほとんど加熱しないで常温で加圧接合する

表 1 溶接法の種類

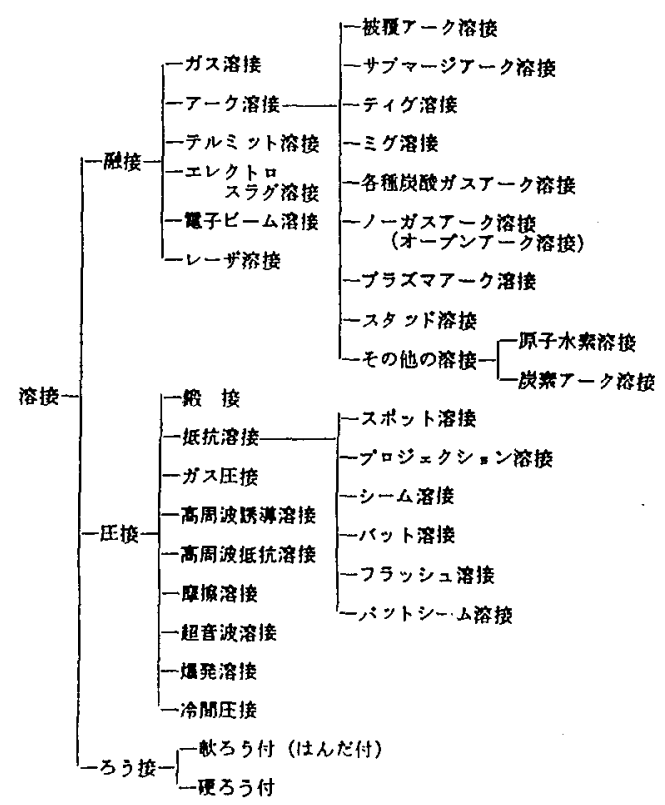


表 2 溶瀜溶接

\begin{tabular}{|c|c|c|c|c|}
\hline エネルギー源 & 熱入力 & 票囲気 & 溶接方法 & 特徵・適用例等 \\
\hline \multirow[t]{3}{*}{ 笔 気 } & アーク & 不活性ガス & $\begin{array}{l}\text { TIG 溶接 } \\
\text { MIG 溶接 } \\
\text { スタッド溶接 }\end{array}$ & $\begin{array}{l}\text { 此較的薄板, 溶接長が艮くなく, 連続しな } \\
\text { い溶接 } \\
\text { 中〜厚板, 溶接が連続して長い場合 } \\
\text { ボルト, ピン等の植込み }\end{array}$ \\
\hline & $\begin{array}{l}\text { 電子の運動エ } \\
\text { ネルギー }\end{array}$ & $\begin{array}{l}\text { 多くの場合真空 } \\
\text { 中 }\end{array}$ & 電子ビーム溶接 & 航空機, ロケット部品等 \\
\hline & 副射 & 不活性ガス & レーザ溶接 & アルミには，切断の形式で実用化 \\
\hline
\end{tabular}

表 3 任接

\begin{tabular}{|c|c|c|c|}
\hline エネルギー源 & 熱入力 & 溶接方法 & 特徴・適用例等 \\
\hline \multirow[t]{2}{*}{ 電気 } & 電気抵抗 & $\begin{array}{l}\text { スポット溶接 } \\
\text { フラッシュパット }\end{array}$ & $\begin{array}{l}\text { 道路標識, 鉄道車両, 航空機等の広筂围の分野で使用 } \\
\text { 二輸車, 四輪車等のホイールリム, 空枠コーナー, 自 } \\
\text { 転車リム }\end{array}$ \\
\hline & $\begin{array}{l}\text { 酥㜔電流による抵 } \\
\text { 抗アーク }\end{array}$ & 高周波溶接 & $\begin{array}{l}\text { 誘禣された高周波の表皮効果を利用して条から各種の } \\
\text { 繶縫管を製造 }\end{array}$ \\
\hline 化学 & 爆発压力変形 & 爆発溶接 & $\begin{array}{l}\text { アルミニウムと異種金属の接合, 異種金属間を溶接す } \\
\text { るトランジジョンピースの製造 }\end{array}$ \\
\hline \multirow[t]{3}{*}{ 機械 } & 摩摽 & 摩擦圧接 & 棒・管の溶接, アルミニウムと異種金属の溶接 \\
\hline & 超音波振動 & 超音波溶接 & $\begin{array}{l}\text { アルミニウム箔, 薄板の接合, アルミニウムと異種金 } \\
\text { 属の接合, ボンデインクヤの接合 }\end{array}$ \\
\hline & 特になし & 冷間圧接 & 線・薄板等の接合, 兆気部品の伝染の接統 \\
\hline
\end{tabular}

方法であり，それ以外はほとんど溶融点以上の温度に加 熱して接合する方法でる。，加熱の方法には継手に直接 電流を流して接合部の温度を上げる抵抗溶接フフラッ シュバット溶接，酸素アセチレンを用いるガス圧接，高 周波を用いる高周波抵抗あるいは誘導溶接，接合面の摩 摖発熱を利用する摩擦溶接がある．表 3 にアルミニウム に利用されている压接法についてその特徽と缡用例を示 す1).

ろう接は母材よりも溶融点の低い合金を溶加金属とし て，母材を溶融することなく継手の狭い間吵を毛細管現 象により接合面に行き渡らせて溶接する方法である。そ してこのろう接は溶加金属のろうの溶融点により約 $450^{\circ} \mathrm{C}$ 以上の硬ろ弓と $450^{\circ} \mathrm{C}$ 以下の軟ろうに分けられ, 前者をろう付, 後者をハンダ付けと呼んだりしている。 表 4 に示すように種々のろう接方法がある.

\section{3. アルミニウムの軠類}

純アルミニウムは数らかく伸展性に富んだ金属であ り,これに $\mathrm{Cu}, \mathrm{Mg}, \mathrm{Si}, \mathrm{Mn}, \mathrm{Zn}, \mathrm{Ni}$ あるいは $\mathrm{Li}$ 等を添 加して合金にすると，機械的性實は改善されそれぞれの 目的に応じた僈れた工業材料が得られる大別すると非
熱処理合金と熱処理合金に妢けられる.アルミニウムは ローマ字 Aと 4 杕の数字 AXXXX で表わすようにJIS H 4000 で決められている.第 1 位の数字は主要添加元素 を表わす．非熱処理合金は，冷間で加工すると加工硬化 により強さが增し，伸びは減少する.このようにして強 さを增した材料を加工硬化材と呼ぶ。これに属するもの としては，純アルミニウム(純度が $99.0 \%$ 以上のアルミ ニウム, AIXXX で表わす), $\mathrm{Al}-\mathrm{Mu}$ 合金, (A3XXX で 表わす), $\mathrm{Al}-\mathrm{Si}$ 系合金 (A4XXX で表わす) 及び $\mathrm{Al}-$ $\mathrm{Mg}$ 系合金 (A5XXX て表わす)がある。熱処理合金は析 出硬化によって機械的性筫が向上する。これ属するも のとしては, $\mathrm{Al}-\mathrm{Cu}$ 系合金 (A2XXX て表わす)， $\mathrm{Al}-$ $\mathrm{Mg}-\mathrm{Si}$ 系合金 (A6XXX で表わす) 及び $\mathrm{Al}-\mathrm{Zn}$ 系合金 (A7XXXで贵わす) がある.非熱処理合金は焼きなま し軟質材(○材という)，あるいは適当な加工硬化の状態 （H材という）で使用される. 熱処理を受けた合金には, 合金部号の後に熱処理記号を付ける. その主なものは次 のとおりである. T4：溶体化処理後, 自然時効硬化させ たもの, T5:滈温加工加ら冷却した後, 人工時效硬化処理 したもの、T6:溶体化処理後, 人工時効硬化処理したも の. 
串 4 万う接

\begin{tabular}{|c|c|c|c|c|c|}
\hline エネルギー确 & 熟 入 力 & 绕同的入力 & 霡 明 気 & ろう终方法。 & 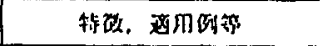 \\
\hline \multirow{6}{*}{ 気 } & $7-\eta$ & \multirow{5}{*}{ 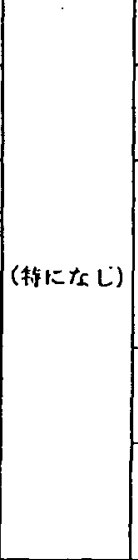 } & 不话性ガス & TIG 万5付 & $\begin{array}{l}\text { フル: } \\
\text { 合 }\end{array}$ \\
\hline & 层每，括抗 & & フラックス & $\sum_{2} Z\left(\check{r}_{1}, 7\right)$ 万弓付 & 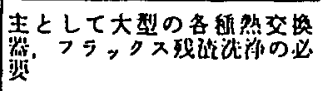 \\
\hline & \multirow{3}{*}{ 夓 } & & フ夸, 気 & 如内万5付 & 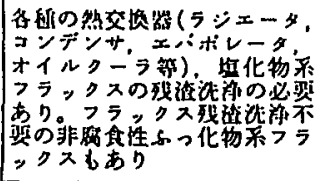 \\
\hline & & & 真 空 & 其空々5付 & 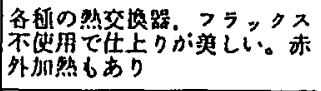 \\
\hline & & & 不括性ガス & 不话性ガス第㽚気万弓付 & 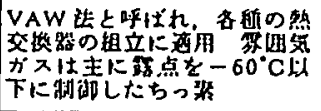 \\
\hline & 层 谋 & 却音设 & 究骶はんだ & 戈音诐はんた付 & 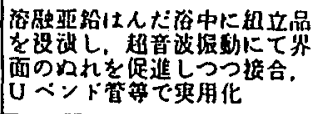 \\
\hline \multirow{3}{*}{ 化 } & \multirow{3}{*}{ ガス炎 } & （特になし） & $>$ オョ,気 & トーチろ弓付 & 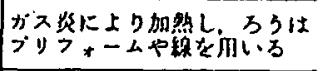 \\
\hline & & 的探 & 大 気 & 䜊㨲はんた什 & 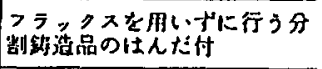 \\
\hline & & (特になし) & フシックス & 反死はんた㑬 & 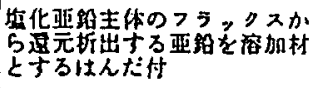 \\
\hline
\end{tabular}

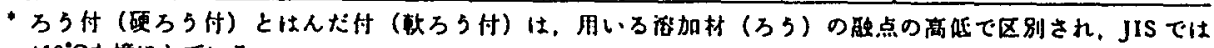
$450^{\circ}$ を筧にしている。

表 5 アルミニウム合金の分類

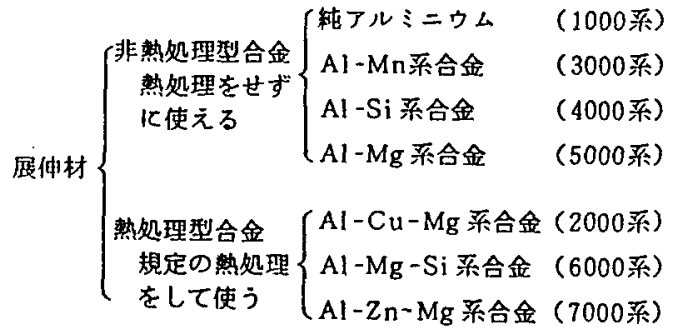

\section{1 アルミニウムの性䨘と楁接性}

非熱処理合金は，一般に耐食性が镸れている，純アル ミニウムは強さは小さいが, 酎食性や加工珄や加工性が 重要となる化学楽品タンク用に使われている， Al一Mg 系合全は軟㗨の状態でも比較的強さが大きく，溶接継手 効率も $100 \%$ 近くになり, 低温じん性が優れているため, 圧力容器, 車両, 船舶, 建材あるいは LNG 用タンク等, 溶接構造物に最も多く使用されている。このようなこと から自動車にもこの系の合金が多く使用するものと考え る.

熱処理合金は，非熱処理合金と比較すると一般に強さ は大さいが,憗食性や溶接性が劣る場合が多い. Al一

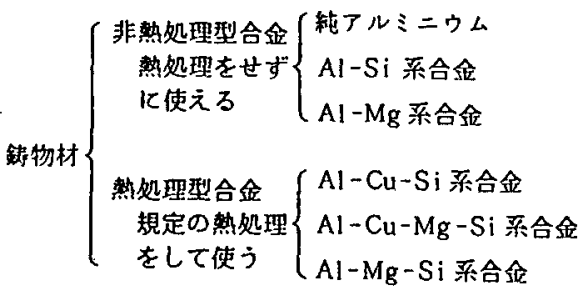

$\mathrm{Mg}$-Si 系合金は欧米などでは広く車両用に用いられて いる. $\mathrm{Al}-\mathrm{Zn}-\mathrm{Mg}$ 合金はわが国においても車両, 建築, 二輪車のフレーム等の溶接構造物に使用されている。一 方 $\mathrm{Al}-\mathrm{Cu}-\mathrm{Mg}$ 系合金(ジュラルミン,超シュラルミン) 及び $\mathrm{Al}-\mathrm{Zn}-\mathrm{Mg}-\mathrm{Cu}$ 系合金（超々シュラルミン）は， 高張力銅に匹敵する強さを持つものもあるが，耐食性が 悪く，溶接が困難なものが多い。ただし， $\mathrm{Al}-\mathrm{Cu}$ 系合金 である 2219 は例外的に溶接性，耐応力腐食割れ性，高温 強さ低温じん性が良いため，ロケット等航空宇宙関係の 溶接棈造物に使用されているので, 自㝡車関係にも使用 されるようになるであう。

新しい材料としては, Al一 Li 合金が航空機用材料とし 
て最近注目されはじめ, 溶接性の検討もされはじめてい

る. 表 5 にアルミニウムの分類を示す2.

アルミニウムの溶接に際しては，鉄鋼材料とは性筫が かなり異なるため, 次の点について気をつけて溶接する 必要がある. 鉄に比へてアルミニウムを比較すると (1)溶融温度は的 $43 \%$ てあるが, 比熱が 2 倍, 溶骶潜熱が 1.5 倍も大きいため, 局部加熱が蜼しく, 溶融させるた めには多量の熱を急速に供給する必要がある。 (2)起張係数が 2 倍と大きく，凝固収樎率が $\mathrm{Fe} の 2.2 \% に$
対して Alでは $6.0 \%$ と 2.7 倍も大きいので, 溶接によ る変形を生じやすい。 また，合金によっては凝固割れ を生じ易い。

(3溶接に際しては表面の酸化皮膜は有害であり、これを 除去するための前処理が必要である. 特にろう付やガ ス溶接ではこの酸化皮膜があると接合ができないため フラックスを用いて除去する方法がとられている。

(4)ほとんどのアルミニウムは溶接熱によって熱影䭗部が 軟化し，溶接のまたの継手の強さは母材の軟㗨材の

表 6 突合せ継手の機械的性質（ミグおよびティグ溶接材 板厚 6〜12 mm）

\begin{tabular}{|c|c|c|c|c|c|c|c|c|c|c|c|c|}
\hline \multirow{2}{*}{ 母材調貿 } & \multirow{2}{*}{ 溶加材 } & \multicolumn{5}{|c|}{ 母材の機械的性頎 } & \multicolumn{5}{|c|}{ 溶接材の機械的性質(1)(2) } & \multirow[b]{2}{*}{$\begin{array}{c}\text { 継手(2) } \\
\text { 奻率 } \\
(\%) \\
\end{array}$} \\
\hline & & \multicolumn{2}{|c|}{$\begin{array}{c}\text { 引张強さ } \\
\mathrm{N} / \mathrm{mm}^{2} \\
\left(\mathrm{kgf} / \mathrm{mm}^{2}\right)\end{array}$} & \multicolumn{2}{|c|}{$\begin{array}{c}\text { 耐力 } \\
\mathrm{N} / \mathrm{mm}^{2} \\
\left(\mathrm{kgf} / \mathrm{mm}^{2}\right)\end{array}$} & \multirow{2}{*}{$\begin{array}{r}\begin{array}{r}\text { 伸び } \\
(\%)\end{array} \\
37\end{array}$} & \multicolumn{2}{|c|}{$\begin{array}{c}\text { 引張強さ } \\
\mathrm{N} / \mathrm{mm}^{2} \\
\left(\mathrm{kgf} / \mathrm{mm}^{2}\right)\end{array}$} & \multicolumn{2}{|c|}{$\begin{array}{c}\text { 耐力 }^{(d)} \\
\mathrm{N} / \mathrm{mm}^{2} \\
\left(\mathrm{kgf} / \mathrm{mm}^{2}\right)\end{array}$} & $\begin{array}{r}\text { 伸び } \\
(\%)\end{array}$ & \\
\hline $1050-0$ & \multirow{3}{*}{1070} & 79.4 & (8.1) & 31.4 & (3.2) & & 79.4 & (8.1) & 31.4 & (3.2) & 25 & 100 \\
\hline $1050-$ & & 109.8 & $(11.2)$ & 103.9 & (10.6) & 8 & 79.4 & (8.1) & 41.2 & (4.2) & 20 & 72 \\
\hline $1050-\mathrm{H} 18$ & & 151.9 & $(15.5)$ & 145.0 & $(14.8)$ & 7 & 79.4 & (8.1) & 41.2 & $(4.2)$ & 15 & 52 \\
\hline $1100-0$ & \multirow{3}{*}{1100} & 93.1 & (9.5) & 38.2 & (3.9) & 35 & 93.1 & (9.5) & 38.2 & (3.9) & 25 & 100 \\
\hline $1100-\mathrm{H} 14$ & & 119.6 & $(12.0)$ & 109.8 & (11.2) & 9 & 93.1 & (9.5) & 45.1 & (4.6) & 20 & 79 \\
\hline $1100-\mathrm{H} 18$ & & 176.4 & $(18.0)$ & 165.6 & (16.9) & 6 & 93.1 & (9.5) & 45.1 & (4.6) & 15 & 53 \\
\hline $2219-\mathrm{T} 81$ & 2319 & 454.7 & $(46.4)$ & 388.1 & (39.6) & 10 & 261.7 & (26.7) & - & & 3 & 58 \\
\hline $3003-0$ & \multirow{3}{*}{1100} & 109.8 & $(11.2)$ & 48.0 & (4.9) & 32 & 109.8 & (11.2) & 48.0 & $(4.9)$ & 25 & 100 \\
\hline $3003-$ & & 144.0 & $(14,1)$ & 138.2 & (14.1) & 8 & 109.8 & $(11.2)$ & 58.8 & $(6.0)$ & 20 & 76 \\
\hline $3003-$ & & 199.9 & $(20.4)$ & 186.2 & $(19.0)$ & 4 & 109.8 & $(11.2)$ & 58.8 & $(6.0)$ & 15 & 55 \\
\hline $5052-0$ & \multirow{3}{*}{5154} & 199.9 & $(20.4)$ & 96.0 & (9.8) & 25 & 199.9 & $(20.4)$ & 96.0 & (9.8) & 22 & 100 \\
\hline $5052-\mathrm{H} 34$ & & 261.7 & $(26.7)$ & 213.6 & $(21.8)$ & 10 & 205.8 & $(21.0)$ & 107.8 & $(11.0)$ & 20 & 79 \\
\hline $5052-\mathrm{H} 38$ & & 290.1 & (29.6) & 254.8 & $(26.0)$ & 7 & 220.5 & $(22.5)$ & 124.5 & (12.7) & 18 & 76 \\
\hline $5154-0$ & \multirow[t]{2}{*}{5183} & 241.1 & $(24.6)$ & 117.6 & $(12.0)$ & 27 & 241.1 & $(24.6)$ & 117.6 & $(12.0)$ & 20 & 100 \\
\hline $5154-\mathrm{H} 34$ & & 289.1 & (29.5) & 227.4 & $(23.2)$ & 13 & 250.8 & $(25.6)$ & 120.5 & (12.3) & 16 & 87 \\
\hline $5083-0$ & \multirow[t]{2}{*}{5183} & 289.1 & $(29.5)$ & 145.0 & (14.8) & 22 & 289.1 & $(29.5)$ & 145.0 & (14.8) & 16 & 100 \\
\hline $5083-\mathrm{H} 32$ & & 317.5 & $(32.4)$ & 227.4 & (23.2) & 16 & 297.9 & $(30.4)$ & 149.9 & (15.3) & 15 & 94 \\
\hline $6061-\mathrm{T} 4$ & \multirow[t]{2}{*}{5356} & 240.1 & (24.5) & 145.0 & (14.8) & 22 & 199.9 & $(20.4)$ & 138.2 & (14.1) & 8 & 83 \\
\hline $6061-\mathrm{T} 6$ & & 309.7 & $(31.6)$ & 295.4 & $(28.1)$ & 12 & 193.1 & (19.7) & 124.5 & (12.7) & 5 & 62 \\
\hline $6063-\mathrm{T} 4$ & \multirow{3}{*}{5356} & 172.5 & (17.6) & 87.2 & (9.1) & 22 & 145.0 & $(14.8)$ & 96.0 & $(9: 8)$ & $\cdots 17$ & 91 \\
\hline $6063-\mathrm{T} 5$ & & 186.2 & $(19.0)$ & 145.0 & (14.8) & 12 & 145.0 & $(14.8)$ & 96.0 & $(9.8)$ & 17 & 70 \\
\hline $6063-\mathrm{T} 6$ & & 241.1 & (24.6) & 213.6 & (21.8) & 12 & 145.0 & $(14.8)$ & 96.0 & (9.8) & 17 & 64 \\
\hline \multirow[t]{2}{*}{$6 \mathrm{~N} 01-\mathrm{T} 5$} & 4043 & 274.4 & $(28.0)$ & 235.2 & $(24.0)$ & 13 & 198.0 & $(20.2)$ & 120.5 & (12.3) & 11 & 72 \\
\hline & 5356 & 274.4 & $(28.0)$ & 235.2 & $(24.0)$ & 13 & 197.0 & (20.1) & 124.5 & $(12.7)$ & 11 & 72 \\
\hline $\begin{array}{r}7 \mathrm{~N} 01-\mathrm{T} 6 \\
(\mathrm{U} 74 \mathrm{~S}) \\
\end{array}$ & 5356 & 389.1 & $(39.7)$ & 326.3 & (33.3) & 11 & 339.1 & $(34.6)$ & 256.8 & $(26.2)$ & 7 & 87 \\
\hline $7 \mathrm{E} 10-\mathrm{T} 6$ & 5183 & 68.4 & $(58.0)$ & 509.6 & $(52.0)$ & 15 & 328.3 & (33.5) & 225.4 & $(23.0)$ & 6 & 58 \\
\hline & & & & & & $\begin{array}{l}\text { (2) } \\
\text { (3) } \\
\text { (4) }\end{array}$ & $\begin{array}{l}\text { 溶接材 } \\
\text { 溶接材 } \\
\text { 継手効 } \\
\text { 溶接材 }\end{array}$ & 际力仕去 & 参考作 & Dる. & & \\
\hline
\end{tabular}


強さにほほ等しくなる。表 6 にアーク溶接部の代表的 強度を示す。

\section{2 溶接绪九}

アルミニウムの溶接部に発生する割れは高温割れであ り，主として結晶粒界における合金元素の偏析あるいは 低虽点化合物に起因するものである。割れは高温割れと いわれ溶接金属が凝固する際，凝固温度範囲の低温側て 凝固時の収縮応力又は外力が作用することによる発生す

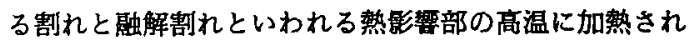
た粒界が局部的に溶融し，凝固する時の収樎力により発 生する割れがある。また多層溶接をした际に，先に置か

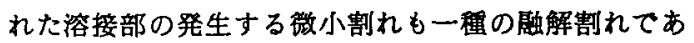
る.

図 1 に 2 元䒺合金の高温割れ感受性と疑固過程の関係 を示す3). 合金成分の量が增大すると共に高温割れ感受 性は增大し，上図のb点に対応する合金量の近くで高温 割れ感受性は最大となり, それ以後は次第に減少して行 く.この図において高温割れ感受性が認められる合金量 は合金元禁の種類により異なり, $\mathrm{Al}-\mathrm{Cu}$ 系においては 1 $\sim 3 \% \mathrm{Cu}, \mathrm{Al}-\mathrm{Si}$ 系に拈いては 0.6〜0.8\% $\mathrm{Si}, \mathrm{Al}-\mathrm{Mg}$ 系においては1〜2\% $\mathrm{Mg}, \mathrm{Al}-\mathrm{Mg}-\mathrm{Si}$ 系においては $1 \% \mathrm{Mg}_{2} \mathrm{Si}$ である。実用合金で $\mathrm{Al}-\mathrm{Cu}-\mathrm{Mg}$ 系, $\mathrm{Al}$ $\mathrm{Zn}-\mathrm{Mg}-\mathrm{Cu}$ 系で割れやすく,純アルミニウム, $\mathrm{Al}-\mathrm{Mu}$ 系, A I-S i 系及び Al-Mg 系では割れが発生しにく い. また Ti, Zn, Ti+B 等の元素を添加し, 結晶粒を微 細化すると割れ防止に效果があることも分かっている。
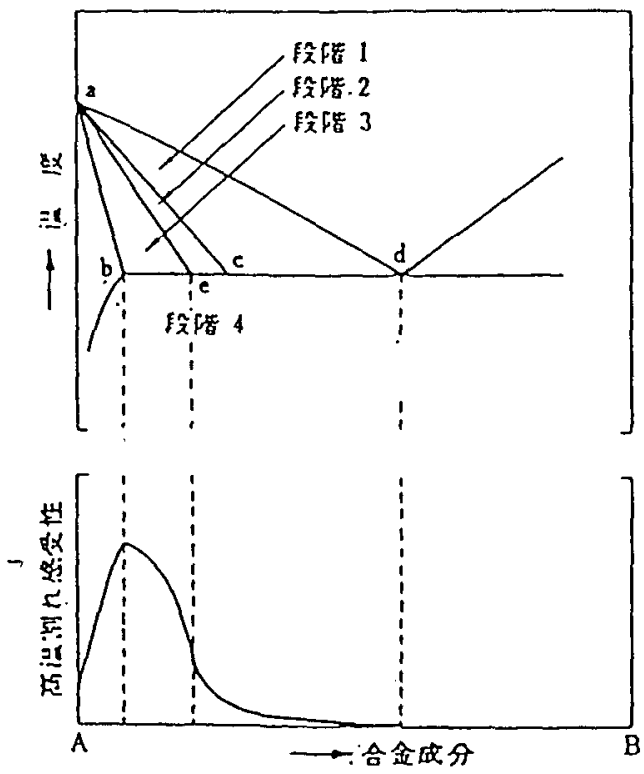

图 1. 2 元系合金の高温割れ感受性と疑固過程の関 係

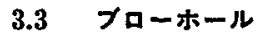

アルミニウムの溶接部にはブローホールが発生しやす く,溶接施工上大きな問題になっている.このブローホー ルの原因は水素であり，アルミニウムは溶辟金属中では 多量の水素を溶解することが可能てあるが，疑固時には その溶解度は激減することに起因している，水素源とし ては種々のものが考竞られるが，特に奇与率の高いもの としては, 空気中の水分, 母材表面及び溶加材表面に吸 着した水分，溶接機器の污れなどが挙げられる.

\section{4. 各 接 合 法}

次に自動車の接合を考えて各接合方法について簡単に 説明する。

\section{1 イナートガスアーク溶接}

この溶接法にはティグ溶接とミグ溶接があるが,いず れもロボット溶接が可能てあり,今後大いに自動車関連 の接合には利用できる.今まで，ミグ溶接は $2 \mathrm{~mm}$ 程度 の薄板は難かしいとされてきたが，溶接機の進歩により ティグと同じように薄板の溶接が可能になってきた。ミ グ溶接の中でミグスポット溶接法があるが, 溶按割れ, ブローホールが発生しやすく, 溶け込みの上からも現在 のところ信賴性が薄いとされているが，荘膡が簡略で作 業性に富むここあるいは片㑡から施工が可能であること など、メリットを有している、このようなことから部品 の接合で抵抗スポットが容易でない所には探用は可能て ある.

表 7 にティグ溶接とミグ溶接の一般的な使い分けの指 針を示すせ.

\section{2 子ピーム溶接}

この溶接法はアルミニウムの物理的性貴を考えると非 常に好ましい溶接方法であるといえるが，榇置が複雑て 高価であったり，接合面の出上の程度，ギャップ，污れ などの管理が䚺しかったり，真空中でないとその利点を 活かせない欠点がある。このようなことから自動車関連 に利用する場合には，厚肉部材で加工精度の良い部材の 接合に適していると考える。

衰 7 ティグ溶接とミグ溶接の使い分け

\begin{tabular}{|c|c|c|}
\hline & ティグ溶接 & ミグ溶接 \\
\hline 板㝵 & 薄板用 (3 mm 以下) & 厚板用 (1 mm 以上) \\
\hline 溶接速度 & 低速 & 高速 \\
\hline 狭箇所部位 & 適 & 不適 \\
\hline 溶接歪 & 大 & 中 \\
\hline 溶接欠陌 & 少ない & プーホール \\
\hline スパッター & なし & あり \\
\hline
\end{tabular}




\section{3 レーザ溶接}

レーザ溶接は鉄銅材料の接合には実用化されているも のの, アルミニウムの接合に実用化されている例は非常 に少ない.しかし, 今後研究開発が進み, 稕々の問題を 解决すれば実用化が可能である。

アルミニウムの接合に利用できるレーザの種類として

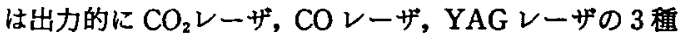
類が考えられるが，いずれも一最一短がある、アルミニ ウムのレーザ溶接が, 実用化されていない大きな理由は, イナートガス溶接のように外観的に滑らかな溶接部が得 られないこと，内部に多数のブローホールを発生するた め気密を要求される場合には不適であること，プラスマ の発生により均一な溶け込みが得られなかったり，奄子 ビームと同じように接合面の仕上げ精度，ギャップが监 しかったり，アルミニウムの溶础粉末の飛散によって、レ ンスが污損しやすい等の欠点があるためである。しかし， 電子ビームのように真空中で接合する必要がなかった ク，YAGレーザを利用すれば光ファイバーを利用する ことによって発振器から $50 \mathrm{~m}$ も逯く睢れた所でも接合 が可能であるといった利点がある. 今後自動車関係には レーザ溶接の利用が大いに期待できると考える゙).

\section{4 抵抗スポット溶接}

アルミニウムの抵抗スポット溶接は，現在非常に幅広 く利用されており，特に道路標識はほとんどこの方法で 組立てられている．鉄道車両関係にも大いに利用されて いる. しかし，アルミニウムは鉄鋼材料に比へて，抵抗 スポット溶接が難かしいと言われており，またスポット 電極のドレッシングなしの連続打点数は非常に少ない. その理由は次の通りである。

(1)固有抵抗が低く，熱后逢率が高いので大電流，短時間 通電が必要である。

(2)アルミニウムは容易に酸化皮膜を生じ，その電気抵抗 が大きく，また均一でないので，接合強度がバラッキ やすい.

(3ナゲット生成の前後において, 塑性範囲がきわめて狭 く, 溶接条件の適正範囲が狭い。

(4)凝固時の体積収縮率が大きく、合金によっては割れや 空洞などの久陷を生じやすい.

(5)高温で急激に軟化するため，匠こんの深さ，板の浮き 上りが大きい.

(6)電極材料とアルミニウムとの固有抵抗の差が少ないた めに電極污損 (ピックアップ) が生じやすい.

このようなことから,アルミニウムを溶接する場合は， 精密な溶接機，例えば三相整流やインバータ式のものを 利用したり，材料の表面処理を工夫したり，電極の材貿
及び形状の適正なものを利用したり，溶接条件の選定を 適正にする必要がある。このように改善することによっ て従来 20 点程度てピックアップを起していたものが, 1000 点近くまて連続打点可能になったという報告もあ Ђ").

今後自動車にアルミニウムが利用されるかどうかは, この抵抗スポットが鉄鎆材料と同じように連続打点数を 增加させることとロボット化を可能にすることにかかっ ていると考える。

\section{2 .1 ウェルドボンド}

抵抗スポット溶接単独の継手では応力集中が発生しや すく, 特に疲れ強さが低くて問題となる場合があり，応 力の分布を均一にすることによる強度の向上並びに耐密 性においてウェルドポンドな有効な方法である。 またこ の方法を用いることによって热抗スポット打点数を少な くすることも可能になってくる。

\section{5 フラッシュパット滵接}

フラッシュ溶接はアプセット浴接によく似ているが, 発熱が材料の端部に集中する，特有な現象によって接合 する方法であり, 現在二輪車, 四輪車のホイールリムの 接合に非常に利用されており，今後益々利用されて行く と考える.このフラッシュバット溶接て改善しなければ ならないことは,フラッシュが周辺に飛散し，また騥音 を発生するので作業愣境を良くすることである。

\section{6 撞圧 接}

摩擦圧接によれば,アルミニウム同志はもちろんのこ とアルミニウムと銅，軟銅，ステンレス銅，チタニウム などの異種金属の接合が可能である．溶接条件因子は回 転数，加熱圧，アプセット圧及び加熱時間などである. 母材の前処理は他の溶接法において要求されるほど政し くない．継手の強さとしては非熱処理合金てはほ浑材 の軟賈材 (O材) 程度であるが，烸処理合金では合金の 種類や調質によって変るが, 70〜95\%程度の継手強度が 得られる7. 現在, アルミニウム同志の管や棒の突合せ溶 接には利用されているし，自動車関係ではプロペラシャ フトの接合やその他円形のものでの接合に利用されると 考える。

\section{7 高周波溶接}

アルミニウムは高周波溶接及び誘導溶接が可能であ り，特に成形装置と組み合わせてフープから管の連続的 な製造を行っている. 押出し性の分る合金やクラッド材 をパイプに押出すことは非常に難しいが，高周波溶接を 利用すれば比較的簡単にパイプの製造が可能である。今 後, アルミのラジエータ及びコンデンサーで利用する偏 平管の製造には大いに期待てきる溶接法てある。 


\section{8 超音波溶接}

金属板の表面を微視的に見ると平滑でなく，重ね合わ せると突起した部分が接触しているが，竫加王と振動に よる滑りによって接触部の酸化皮膜などが破壊除去さ れ, 清浄な両同志が互いに接触すると共に, 弾性変形や 望性変形，さらには摩擦熱による温度上昇が加わって， 接触面間に原子間引力が作用し合う程度まで近接し溶接 にいたる。この超音波溶接はスポット及びシームの形態 で行われ，アルミニウムの箔や薄板の溶接, コンデンサ 用アルミニウムケースのリード線の溶接，アルミニウム と銅の異材の溶接, その他シリコンウェーハとアルミニ ウム線の溶接にも利用されている。また抵抗スポット溶 接に代わるものとして採用されたこともあるき.

\section{5. $3 う$ 付}

アルミニウムのろう付技術は非常に進んでおり，自娌 車部品である熱交換器はほとんどろう付で組み立てられ ている.これらの熱交換器のろう付法としては, 従来, フラックスを用いたろう付が主体であったが、この方法 によるとフラックス洗浄夜の公害の問題や洗浄不良によ る腐食の問題があった。 そこで最近では多量生産に向く 真空ろう付法が開発されたり，不活性壆囲気ろう付や， 非腐食性フラックスを用いたろう付法が開発されて広く 利用されるようになってきた。熱交換器部品の接合には 益々ろう付が採用されて行くと考える。

\section{6. 接}

接着接合は世の中的には非常に多く利用されている技 術であるが,アルミニウムの構造物の接合には余り利用 されていないのが現実である。しかし，航空機分野では 接着がかなり利用されている。接着接合の長所と短所に ついて考えて見ると，長所としては

(1)接着部において荷重は，より平均的に分配される。応 力集中は少なくなる。それゆえ，より大き疲労寿命が 得られる。

(2)接着剤は,膨張率の異なった異種金属を接合した場合， その界面に発生する応力を小さくするように働く。

(3)接着阂による接合は，振動を減衰させる働きがある。

(4)高価な機械設備や金属加工操作がいらないため，接合 コストを低隇できる場合がある。

(5)軽量化による節約が可能になる。

(6)接着によって電気絶縁性をもたすこともできる。また 電気伝導性が必要なところには,やや高価ではあが， 尊伝性の接着剤を利用することができる。

(7)接合部において接着剛によってもたらされる丽気絶縁
性により，異種金属間の電食を減少させたり，なくし たりすることができる。

(8)接合部の外面を平滑にし，美観を高めることが容易て ある。

などがあり，短所としては，

(1)前処理の洗浄工程または接着剂の塗布工程に費用がか かりすぎたり，高価なジグが必要であったりする。

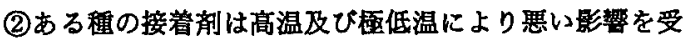
ける.

(3)接着剂接合の耐候性についてのデータが非常に少な い. 外界にさらされた時の接合部の寿命ははっきりわ かっていない.いいかえれば信頼性に欠ける。 (4)硬化時間が製造工程を制限する場合がある。 などが考えられる。

現在自動車は相当な部分で接着接合が行われている が,アルミニウムの接着を良好に行うためには，接着鼡 の選定, 前処理工程, 接着剂の塗布方法, 硬化法が非常 に大切である。

\section{7. 機械的接合}

機械的接合には，一般的な接合法としてリベット接合， 機械的成形接合，ねじ止めなどが古くから知られている。 これらの接合法をアルミニウムに適用することは可能て あるが，実際に用いる場合設計の段階においてその接合 部が要求する機能を果たすのに必要とされる強度，機械 的な特性，洒格，外観，酎食性等を考盧して決定すへき である.表 8 に現在利用されている機械的接合への種類 を示すが, 自動車関係ては，この中てりべット接合が最 も広く利用されており，はぜ継きやメカニカルクリンチ ングのような機械的成形接合も利用されている.

8. 材料の取り扱いと切断について

ア゙ルミニウムは軽量で製作時の運搬は楽であるが，反 面キズがつきやすいこと，油などによる污染が接合の時 欠宿の原因となるのでその取扱いには鉃鋼材料より傎重

表 8 機械的結合法の種類

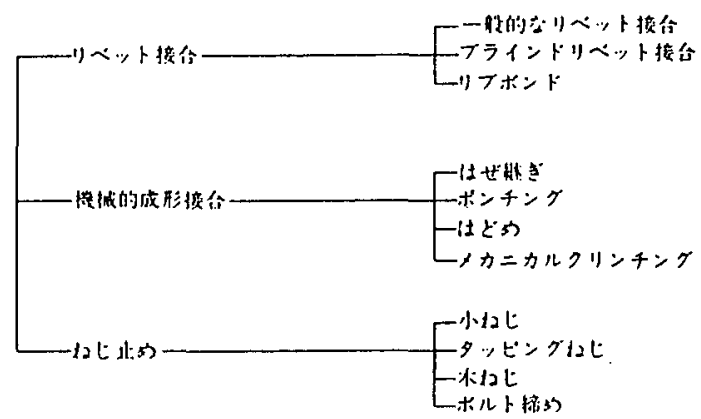


にする必要がある。

アルミニウムの切断は,ガス切断が適用できなく、ほ とんど機械切断に頼ってきたが，最近レーザ切断が可能 になり，少しずつ利用されるようになってきた．板厚 8 $\mathrm{mm}$ 程度まではかなり精度良いレーザ切断が可能に なった．現在実用化されているレーザは $\mathrm{CO}_{2}$ レーザと YAGレーザであるが，どちらを利用しても良好な切断 が行われる.しかし, $10 \mathrm{~mm}$ 以上の厚板や押出し形材の ような複雑な断面形状のものはレーザ切断は不可能なの で,これらの切断は従来通りの機械的切断に頼らさるを 得ない.これ以外プラスママ切断やウォータジッット切断 も利用されているが，自動車関係では，必要ない方法と 考える。

\section{9. 接合部の性䨢について}

以上自動車に関連したアルミニウムの主な接合法につ いて解説したが，このような各種の接合法で接合した部 分の性質はどのようになるか簡単に説明する．接合部に 要求される性貿としては機械的強度, 物理的性實, 化学 的性質の3つである。これらが接合される前の母材の性 質と同等もしくはそれ以上であれば良いわけてあるが， アルミニウムの接合の場合，母材のそれ以上になること はない。したがって如何に母材の性質に近い接合部を作 るかが技術者の役目でると考える。

一般に熟を加え材料が溶暨・凝固して接合が行われる 場合，アルミニウムはいずれの合金も強度的には，その 合金の軟䨘材 (O 材) 相当に強度は低下する.もちろん 接合における熱エネルギーの大小によって低下の程度は 異なるが，それ程大きな違いはない。また1部の合金は 時間の経過と共に強度が回復するが，100\%回復するこ とはない. 物理的及び化学的性貿も強度と同じように， ほとんどの合金が低下する方向に向かうと考えて良い。 特に化学的性質などは，合金によって著るしく低下する
場合があるので注意する必要がある.

熱を加えない接合の場合は，健全な接合部が得られれ ほ，機械的性貿，物理的性質及ひ化学的性實は母材の性 䨘とほとんど同じでる。しかしながら，実际に母材と 同等の性實の接合部を得ることは至難なことてある。

\section{0. むす び}

かが国における自動車に対するアルミニウムの使用量 は次第に增加して扔り，昨年ホンダが販壳したNSX のアルミニゥムの使用量は全車体重量の $35 \%$ 程度であ る.しかし，一般の自動車のアルミニウムの使用量は末 だ $5 \%$ 程度である.今後，アルミニウムが益々自動車に 利用されるには接合技街が非常に重要な課題となる。

今度，自動車用材料の溶接・接合技術という中てアル ミの接合技術の執筆にあたり，非常に籍囲が広いてすが、 できるだけアルミの接合技術を理解してもらうため，現 在利用されている接合法及び将来利用されるであろう接 合法について広く浅く解説した.これからアルミニウム がより合理的より経昘的に自動車材料に利用されるた めには，種々の問題点がまだ多く存在するが，今後更な ろ研究開発に期待したい.

\section{考文 嗝}

1）麻野：アルミニウム接合，軽金属，1990,7

2）軽金属溶接構造協会：アルミニウム溶接入門講座

3）内田：轾金属溶接 No. 13 '64. P. 12.

4）㪕金属溶接技術会：アルミニウムとその合金イ ナートガスアーク溶接, (1971)

5）平本他，第 114 回溶接法研究委員会, SW-179987

6) 自動車技術会中部：“1990 年度自動車技術談話会 資料” 1990 年 6 月 14 日

7）轻金属協会，自動車のアルミ化技術ガイド，昭和 56 年 11 月 15 日, 接合程

8）小玉：“非鉄金属の超音波溶接”，軽金属溶接，vol. $26,1988,6$ 